\title{
Audio Materials in Academic Research Libraries
}

\begin{abstract}
Questionnaires and in-person visits to large academic libraries in 1971 form the basis of this report which reveals the low priority given to nonprint materials by the majority of these libraries. Visuals are practically nonexistent; audio materials remain eclipsed by print. Nonprint collections tend to be initiated from stimulation outside the library, and, once established, suffer from space and maintenance problems while the research potential is largely ignored.
\end{abstract}

\begin{abstract}
A Audiovisual materials are commonplace in school and college libraries, and the literature on the theory and application of selection, preparation, and use of these materials is extensive. However, the research library director who is considering the introduction of nonprint media into his library encounters a dearth of useful background information. In 1967 the writer was asked to prepare a set of specifications for a dialaccess information at the University of Utah. The job was made more difficult because a literature search produced little of substance. Even in 1971 it was still not possible to determine what institutions have facilities and how they are used.
\end{abstract}

The writer, therefore, undertook a survey of audiovisual materials in research libraries with a Council on $\mathrm{Li}$ brary Resources Fellowship Grant.

A questionnaire was developed, tested, and sent to all academic libraries in the Association of Research Libraries to determine which institutions collect and service audiovisual materials. Sixty-

Richard W. Boss is director of libraries, the University of Tennessee, Knoxville. eight of the seventy-five libraries queried responded, a satisfying 90.7 percent.

Seventeen institutions, 25 percent, reported that they had no audiovisual materials. One reported no materials, while indicating that plans were being made to include such materials in a new building.

The fifty remaining questionnaires were analyzed to determine which institutions should be visited. Seventeen, or 34 percent, were selected for an in-person visit for one of the following reasons: (a) a large audiovisual materials collection, (b) a significant investment in audiovisual equipment, or (c) a statement of strong commitment to audiovisual service.

The availability of audio materials and services in academic research libraries is still extremely limited. Visual materials and services are even more limited. Only twelve of the seventy-five institutions collect films, film strips, slides, or other visual materials. If slide collections are eliminated, less than half a dozen institutions own more than a hundred items. This apparent lack of commitment is in sharp contrast to the alleged acquisitions policies of thirtyeight of these libraries, which report 
their policy is to acquire materials without regard to physical format so long as they relate to the teaching and research programs of the university.

One explanation for the emphasis on audio rather than visual materials in the library is the existence of a campus audiovisual center outside the library on at least thirty-nine of the campuses. Most of the centers have extensive film collections and limited collections of other visual materials. Because the holdings of visual materials proved so sparse, the study of contemplated visual materials and services was abandoned.

Interviews with librarians revealed that most of the programs were begun as the result of an academic department taking the initiative. In twenty-eight of the fifty cases the initiative was provided by the music department. Eighteen of the principal listening facilities are located in music branch libraries. On twenty campuses where the primary installation is in the main library, there is a secondary listening facility in the music library. On ten campuses the primary installation is in the undergraduate library. These facilities were usually established at the time the undergraduate library was built, and they constituted the first commitment of the library to listening facilities. Two campuses have campus-wide systems, not operated by the library, but by a special agency. However, most of the listening positions are in the library.

The number of patrons served by the listening facilities range from as few as 130 per month to as many as 120,000 per month as is summarized in Table 1 .

Only nine of the fifty facilities can be considered major. Less than 5,000 uses per month would be less than one use per student per month on any of the campuses. On most campuses, it would mean less than one use per student per quarter.

There appears to be little relationship between the amount of use and the size of the collection. The two institutions with the highest use rank below the median in collection size, while five of the ten institutions with the least use rank in the top quartile of collection size.

Only two institutions have more than 50,000 recordings. Sixty percent of them have between one thousand and ten thousand recordings. Three owned fewer than 500 recordings.

Nine institutions use phonodiscs exclusively in their music-listening facilities. Thirty-two use both audiotapes and phonodises, but mostly phonodises,

TABLE 1

\begin{tabular}{|c|c|}
\hline \multicolumn{2}{|c|}{$\begin{array}{l}\text { Number of Patrons SeRved PER MONTH } \\
\text { BY THE LISTENING FacturtiEs }\end{array}$} \\
\hline $\begin{array}{l}\text { Over } 100,000 \\
50,000 \text { to } 100,000 \\
25,000 \text { to } 50,000 \\
10,000 \text { to } 25,000 \\
5,000 \text { to } 10,000 \\
2,500 \text { to } 5,000 \\
1,000 \text { to } 2,500 \\
500 \text { to } 1,000 \\
\text { Less than } 500 \text {. } \\
\text { No statistics kept } \\
\text { Didn't answer. }\end{array}$ & $\begin{array}{l}\text { One } \\
\text { None } \\
\text { One } \\
\text { One } \\
\text { Six } \\
\text { Seven } \\
\text { Eight } \\
\text { Six } \\
\text { Two } \\
\text { Nine } \\
\text { Nine }\end{array}$ \\
\hline
\end{tabular}

whereas nine institutions use audiotapes only. Those using audiotapes only reported the largest number of users. These institutions have found that phonodiscs will not hold up under heavy use and have converted to audiotapes. The two largest facilities began with audiotapes, however.

Twenty-five of the fifty listening facilities are primarily music-listening systems, while eleven were set up to serve the needs of departments concerned with English literature. In two cases the systems were set up specifically for poetry listening. Four of the systems were designed for recreational listening specifically. Overall, in twenty-four systems recreational listening constitutes a substantial percentage of the total use.

Three systems are language-listening 
systems, not of the drill variety, but systems which feature plays, poetry, and speeches in foreign languages to supplement classroom and laboratory training. Three other systems were set up specifcally to support zoology, mechanical engineering, and speech, respectively. In four cases, the principal purpose of the system was not identified.

The vast majority of the systems are used by three or fewer academic departments because only three of the institutions are actively promoting listening facilities among faculty. Users of the library are usually not directed to the listening facility through the card catalog. Thirty-eight of the institutions do not include audio materials in the main card catalog; nine do, and in three, partial listings are recorded: in one case, phonodiscs only; in another, spoken materials only; and in another, main entry only for all materials.

The differences in attitudes toward audio and print materials becomes apparent as one talks with directors, acquisition librarians, and cataloging heads. Most agree that audio materials are important, but give them a lower priority than printed items. Only in those institutions where the processing of audio materials is done in the listening facility is there no significant backlog. In the cataloging departments of main libraries, audio materials are given a lower priority in all but three institutions. In only one library do the materials receive a higher priority.

The majority of the systems are located in basements, on top floors, or in other low-priority locations. All listening system heads reported great difficulty in competing with other library departments for space.

The most serious condition observed, however, is the poor maintenance of equipment. One third to one half of the equipment was down at the time of the visit. In most of the facilities visited, there is a lack of technical compe- tence on the part of the staff, and preventative maintenance agreements with qualified firms are the exception rather than the rule. The materials are also in poor condition, especially the phonodiscs. Music librarians who said they chose phonodiscs over audiotapes because they want to provide better service, seem to have more scratched phonodiscs, poor cartridges, and a larger number of machines out of order than those libraries which use audiotapes. Again, the two largest systems, operated by nonlibrarians and staffed with technically trained personnel, have the best quality materials and the lowest equipment downtime.

The predominant complaint of all the listening-room attendants and supervisors consulted is poor maintenance. Interviews with students on the campuses reveal substantial displeasure with the quality of equipment maintenance and the condition of phonodises and audiotapes. This suggests that an institution should not seek to provide this service unless it is prepared to hire a technically qualified person to maintain the system or contract this to an electronics firm.

In general, facilities which use dial access (8) have the best maintenance and the highest user satisfaction. Those with central control rooms rank next, and those which provide turntables and tape decks for hands-on control by students have the lowest level of satisfaction. Those who have chosen the individual units said they chose them because they felt this would be more popular with patrons. It appears that patrons prefer to sacrifice hands-on control in order to get greater reliability and higher program quality.

Ten of the institutions allow materials to be circulated, while twenty-five do not, under any circumstances, permit circulation. Eight permit faculty to charge out materials, three more allow occasional loans to different classes of patrons. Four institutions not visited did 
not answer the question. Generally those circulating materials have collections of phonodiscs. All but one of the libraries circulating materials reported that their collections are in poor condition.

Thirty-seven of the institutions allow no reproduction of their materials, two allow occasional reproduction, five did not answer, and six permit unrestricted reproduction. Only one of these produces all of its own materials. The five which allow the reproduction of copyrighted materials expressed no strong concern about copyright infringement. It is interesting, too, that one campus with two listening facilities restricts reproduction in one for fear of copyright infringement and openly allows it in another because copyright infringement is not considered a problem.

A review of the existing listening facilities reveals such a broad range of attitudes and practices that it is difficult to generalize. There is no question that audio materials are far less important than print materials. Libraries have responded to demands from patrons in most instances rather than seeking to innovate by offering a wider range of media for the support of teaching and research.

Research use of audio materials is conspicuously absent on all campuses. Even those most strongly committed to audio materials in research libraries think of them only as teaching and recreational materials. Three of the campuses have separate archives for recorded sound. It was the heads of the archives who demonstrated concern for research. Their collections tend to be extremely large, well preserved, and infrequently used, with very strict quality control.

There are thousands of high quality phonodiscs and audiotapes of music, drama, poetry, speeches, and interviews available at reasonable prices. The acquisition, processing, and servicing of audio materials by university libraries would strengthen research on university campuses. Understanding and appreciation are enhanced when one hears the inflection in the spoken word or the interpretation of music by an outstanding performer or conductor.

The written text of a Roosevelt "Fireside Chat" cannot possibly convey the significance of this use of the radio medium for seeking political consensus. A comparison of performance of classical music is basic to musical research. Audio materials should be an integral part of each library's collection, but they won't unless we begin to look beyond physical format to content and usefulness. 